\title{
Women's organizations in 1990s Turkey: predicaments and prospects
}

\section{Simel Esim \& Dilek Cindoglu}

To cite this article: Simel Esim \& Dilek Cindoglu (1999) Women's organizations in 1990s Turkey: predicaments and prospects, Middle Eastern Studies, 35:1, 178-188, DOI: 10.1080/00263209908701261

To link to this article: https://doi.org/10.1080/00263209908701261

\section{Published online: 06 Dec 2006.}

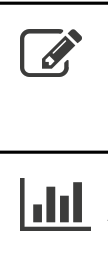

Submit your article to this journal ๘

川 Article views: 357

4 Citing articles: 12 View citing articles $\asymp$ 


\title{
Women's Organizations in 1990s Turkey: Predicaments and Prospects
}

\author{
SIMEL ESIM and DILEK CINDOGLU
}

This article analyses the nature and the structure of women's organizations in 1990s Turkey. It surveys women's organizations and attempts to position them in their national and international political contexts by reviewing the types of gender need addressed by them. It also positions women's organizations by grouping them according to their larger historical and political agendas within the country.

Women's organizations are defined as organizations whose founders and beneficiaries are women. Women's agency through collective action, in the form of women's organizations, is crucial in transforming the politics of gender in Turkey. Looking at the predicament and prospects of these women's organizations provides an important insight into the changing gender politics in the country.

Women's organizations in Turkey can be analysed on two levels. On the macro level, they are indicators of the collective capacity of women to determine the politics of gender in contemporary Turkey; and on the micro level, they are forces of change working to improve the well-being of women with programmes on health, education and income generating activities.

Women's organizations are influenced by political and social approaches to gender issues in Turkey, past and present. They are also affected by the changing approaches to gender and development issues by international donor agencies, due to the financial support and technical assistance that they receive from these institutions. In summary, this study examines first of all women's organizations in historical and political context and makes an account of their impact on social and political agendas. It discusses the organizational capacity and potentials of these organizations in the contemporary political climate of the $1990 \mathrm{~s}$, and points out some of the possible institutional structures and co-operation between women's organizations, government agencies and international donors which could be developed in order to achieve the policy objective of gender equality.

The political culture of Turkey poses a number of obstacles to women's participation in the public arena, particularly politics. Women's 
organizations face the challenges of the mainstream political culture which stems from the predominantly male-dominated politics where communications with civil society institutions are limited. The political and institutional traditions are such that the political sphere is mainly defined by the state elite in Turkey. The forces of civil society still do not have much power in the formation of politics. ${ }^{1}$

Women's organizations, as institutions of civil society, have little power in this process. They are further alienated from the political process due to the fact that they are run by women in a social climate where men are the main actors. The gender hierarchies, which are established systems of power that privilege men with respect to women, limit women's effective interactions and communications in this sphere. In addition to these gender hierarchies, limited public and private funds make the work of women's organizations harder. ${ }^{2}$

The existence of non-state actors in international development has been the subject of much research. Non-governmental organizations are becoming more institutionalized and the scope of their interventions is growing constantly. ${ }^{3}$ According to Therien, the different generations of nongovernmental organizations can be categorized into four groups according to their charitable, developmental, participatory or globalist approaches. While Therien's classification is useful for the analysis of nongovernmental organizations, for the purposes of this study women's organizations in Turkey need to be classified according to the gender needs they satisfy.

The attempts to include gender in the study of non-governmental organizations need to be multi-layered since women do not constitute a homogeneous group. The category of 'woman' is based on differences of class, ethnicity, religion and community. However, women have organized around a number of common goals and interests relating to their gender needs. These needs can be grouped into two categories: practical and strategic gender needs. ${ }^{4}$ Caroline Moser suggests that practical gender needs are those identified in women's accepted roles in society which generally do not challenge the gender division of labour or women's subordinate position in society. They are practical in nature and are concerned with inadequacies in living conditions such as water provision, health care and employment. They are local and short term in nature. Addressing them requires a change in particular gender-based conditions but need not involve a transformation of gender hierarchies. On the other hand, strategic gender needs arise from a more general analysis of women's subordination and involve strategic objectives to overcome that subordination. They relate to gender divisions of labour, power and control and may include such issues as legal rights and domestic violence. 
Therefore, they are large scale and long term in nature and require fundamental change in order to eliminate gender hierarchies. ${ }^{5}$

Throughout the world, women's formal and informal organizations set out to address one or the other and sometimes both of these gender needs. Women's organizations which deal with women's practical needs are generally involved in reformist politics, while those which focus on strategic gender needs embrace more transformative politics. For instance, in Malaysia, the Malaysian Women's Aid Organization, organized around strategic gender needs, provides a range of support services to women with violent husbands including shelter, counselling and legal advice. The Women's Development Program in India is a voluntary agency serving practical gender needs and working in the field of adult education and rural development for women. In the Philippines, GABRIELA, an alliance of local and national women's organizations addresses both practical and strategic gender needs by running a tapestry-sewing project and discussing women's legal rights and changes in the constitution. ${ }^{6}$

Women's organizations in Turkey can also be positioned within the context of these two different yet connected gender needs. There is a long history of women's organizations in Turkey. They have developed across the political spectrum in response to influences such as changes in the focus and priorities of donor agencies, the history of political movements in Turkey, and contemporary power struggles among political and social groups in Turkey.

The data used in this research were gathered by the authors between January and August 1995. During this period around 100 personal and institutional interviews were conducted with women's organizations in Turkey. The length of the interviews varied between 20 minutes and 2 hours. Most of the interviews were held in the two metropolitan areas of Istanbul and Ankara. Five smaller provinces were also visited: Urfa, Mugla, Denizli, Gaziantep and Corum. In these provinces, too, members of women's organizations were interviewed. As a research strategy, a comprehensive list of women's organizations, provided by the Turkish Directorate General on the Status and Problems of Women (DGSPW), was targeted. These personal and institutional interviews were conducted within the confines of an extensive, nation-wide socio-economic study on women's micro and small enterprises in Turkey. The institutional interviews were one of multiple research methodologies used to find out about the conditions of women's micro and small businesses and the gender-based, cultural and institutional constraints they face.

The history of women's organizations in Turkey needs to be seen within the context of power struggles among the country's political and social groups. 
The Turkish Republic was established in 1923, with a 'modernistnationalist-secularist' agenda contrasting with that of Islam and the monarchy that preceded it. Being the first country to launch a project of modernization in the Middle East, the Kemalist reforms sought the 'emancipation of women' and made significant progress in terms of legal and political rights, education and labour force participation. According to Kandiyoti, the 'new woman' of the early years of the Turkish Republic became the symbol of the break with the past. The 'paternalistic benevolence' of the Kemalist reforms with respect to women and women's rights provided the platform of 'state-sponsored feminism' for many decades to come.?

The 1980 military coup in Turkey initiated a political vacuum by banning almost all former political activities of the political parties, associations and unions. During the early 1980 s, women who were part of the socialist movement prior to the ban of the military established feminist women's groups. The feminist women's groups were created when women started to review critically their own roles and participation in the socialist movement. ${ }^{8}$ From the early 1980s, feminists began to question Kemalist ideology in terms of its effect on women. While the socialist movement and the feminist women's organizations had initiated their own critique of Kemalist reforms from the early 1980s, it was the rise of radical Islam that decisively determined the positions of women's organizations in the political spectrum. The nationalist and secularist forces in society defended Kemalism in general and the Kemalist reforms for women specifically against the Islamic critiques.

The radical Islamic theoreticians launched an extensive review and critique of the impact of Kemalist reforms on Turkish society and politics. The position of women in society was one of their foci. Since then, the radical Islamic ideology has gained popularity across Turkey, especially among the urban working classes and urban squatter areas. The success of the populist rhetoric of the popular Islam of the Welfare Party (Refah Partisi) has not been matched by any other major political movement during this period.

Women's organizations are established as associations or foundations in Turkey. While associations emphasize human resources and membership, foundations focus on assets and the distribution of resources. Foundations are traditional social institutions of goodwill inherited from the early days of the Ottoman Empire. Foundations and associations are subject to the provisions of the Civil Code. Both have to secure state approval and financial reviews in order to operate.

The collective strength of women through women's organizations can be transforming, especially for the lives of poor women with limited education 
and skills. However, none of the women's organizations discussed in this article was initiated by poor women in Turkey. These groups came into existence through the efforts of relatively powerful actors/actresses who have access to the necessary education, information, funds and contacts. While the motivations of the founders are mostly altruistic, they are also guided by implicit or overt political agendas.

Most of the women's organizations are not fully self-sufficient financially. Associations depend mainly on membership dues, while foundations receive private donations to cover their operating costs. For special projects and programmes, both groups rely on resources from related state ministries, collaborating institutions (local NGOs, private foundations) and international donors. The unpredictable nature of the flow of funds results in the programmes having limited reach and little continuity.

The founders of these organizations are mainly urban middle-class, professional women while the beneficiaries of these programmes are mainly urban lower middle-class or squatter area women. The relationship between the founders of the groups and the beneficiaries are mostly vertical/hierarchical. The motives of the women and men who found and run these organizations are altruistic and populist in nature. However, while they might 'want to save the poor' by sharing their knowledge and expertise, redistribution of wealth and social justice are not on their agendas.

In the light of our findings, women's organizations in Turkey are categorized into three groups according to their political agendas: Kemalist, Feminist and Islamist. In each of these categories the women's organizations discussed have a wide variety of programmes in family planning, skills training, income-generating activities, consulting services, fairs and exhibits, child care centres, battered women's shelters, libraries, publications, seminars and conferences. ${ }^{10}$

Most of the women's organizations in Turkey pursue a strictly nationalist and secularist agenda. These Kemalist women's organizations include the Turkish Women's Union (Turk Kadinlar Birligi), the Association to Support the Modern Life (Cagdas Yasami Destekleme Dernegi), and the Association to Research Women's Social Lives (Kadinin Sosyal Hayatini Arastirma Dernegi). Their programmes mostly address a combination of strategic and practical gender needs through. Their activities include seminars on women's legal rights, skills training courses for income-generating activities. They perceive women as citizens and productive members of society with the belief that by illuminating women with Kemalist ideals, the secular nature of the state will be secured.

There are several common characteristics among the women's organizations in this group. First of all, they define the origins of their 
organizations with the 'state feminism' of the Kemalist reforms, particularly those favouring women's participation in the public sphere. These reforms are the introduction of the Swiss civil code abolishing polygamy in 1926, the banning of the veil and the Islamic dress code for women in 1935, and the establishment of the right for women to vote and to be elected.

Secondly, as the radical Islamic politics gained popularity among urban working class neighbourhoods and squatter areas and in general among the disenfranchised in Turkey, Kemalist women's organizations started to pursue a mission to persuade poor women living in urban working squatter areas or small towns toward Kemalist, nationalist and secularist ideas. Of these organizations the Association to Support Modern Life focuses on seminars on topics such as legal and political rights of women. The Icerenkoy Family Consultative Centre in Istanbul trains volunteer women in the teachings of Atatürk and the Qur'an simultaneously in order to convince the neighbourhood women of the importance of secular principles in their lives.

Thirdly, these women's organizations mostly support family planning programmes, without a serious critical perspective. However, due to their limited grassroots reach, it is not feasible for them to undertake substantive family planning programmes on their own. Stemming from the idea that women with fewer children will be more healthy, productive and able to take better care of their children, these organizations work closely with other national and international family planning agencies on disseminating information on family planning, distributing contraceptives and providing Information Education and Communication (IEC) services on family planning.

Fourthly, most Kemalist women's organizations conduct some welfare and poverty reduction programmes. They provide training in traditional skills - courses in sewing, embroidery, carpet weaving, tricot - and limited marketing facilities for women entrepreneurs to sell their products through daily exhibits and fairs. However, none of these activities has extensive reach. Their programmes target only a limited number of women in one or a few urban squatter areas and a limited number of villages or small towns in rural areas. Moreover, the training courses reinforce the traditional household roles of women. The exhibits and fairs they organize serve as fundraisers for their organizations rather than marketing opportunities for women entrepreneurs (see Table 1).

Islamic women's organizations such as the Ladies' Culture and Education Foundation (Hanimlar Kultur ve Egitim Vakfi) specialize in seminars on topics such as women's role in Islam, the Islamic family and women's place in the Qur'an. They also provide food and clothing aid for poor, female headed households in urban squatter areas of Istanbul. There 
TABLE 1

WOMEN'S ORGANIZATIONS IN 1990S TURKEY

\begin{tabular}{llll}
\hline & Kemalist & Islamist & Feminist \\
\hline Gender Needs & strategic/practical & practical & strategic/practical \\
Development Strategies emancipation, & welfare & $\begin{array}{l}\text { gender equity, } \\
\text { gender equity }\end{array}$ & nowerment \\
Political Agenda & $\begin{array}{l}\text { secularist, } \\
\text { nationalist }\end{array}$ & $\begin{array}{l}\text { (religious) } \\
\text { Target Population }\end{array}$ & urban/rural women \\
Programs & $\begin{array}{l}\text { urban poor families } \\
\text { skills training } \\
\text { courses, seminars }\end{array}$ & $\begin{array}{l}\text { food aid, training } \\
\text { courses, seminars }\end{array}$ & $\begin{array}{l}\text { urban poor women } \\
\text { battered women and } \\
\text { child care centres }\end{array}$ \\
\hline
\end{tabular}

are strong ties of co-operation among Islamic women's organizations, the Islamic Welfare Party Municipalities and other Islamic organizations and individuals in the country. The widely circulated Islamic journals that target a female audience discuss a large array of issues related to women's lives and include information on the activities of the Islamic organizations. The journals provide a public relations service for Islamic women's organizations in recruiting volunteers and participants in their programmes.

Islamic women's organizations mainly deal with women's practical gender needs. However, they perceive women mostly in the context of their families, as wives and mothers. This would appear a contradiction in terms since the women who found and run these organizations, by working and being active outside their homes, define themselves mainly outside their families as activists who are part of the radical Islamic movement in Turkey rather than as mothers or wives.

The programmes run by the Islamic women's organizations have several important characteristics. First of all, they are mostly welfare programmes which create a relationship of dependency on the women they help. Food and clothing aid helps poor families financially, but the programmes do not provide a permanent solution to their needs, such as training for incomegeneration activities and business skills. Secondly, they have extensive grassroots reach and support from Islamic groups and individuals as well as municipalities where the religious Refah Party is in power. This kind of networking and pooling of resources among Islamic organizations makes their operations more extensive and efficient.

Thirdly, their services are mainly, although not exclusively, used by women who opt for a religious lifestyle. Many women who visit the organization and receive aid from it cover their heads and follow a more 
religious way of life. Fourthly, the programmes provide rare outlets for young women in conservative social environments to get out of the house and attend activities. The families of most of these young women would only allow them to go on the Qur'an courses, seminars or training courses organized by Islamic women's organizations (see Table 1).

There are only a few women's organizations with a feminist agenda in Turkey, such as the Purple Roof Women's Shelter (Mor Cati Kadin Siginagi), the Foundation to Support Women's Work (Kadin Emegini Degerlendirme Vakfi) and the Altindag Women's Solidarity Foundation (Altindag Kadin Dayanisma Vakfi). By the nature of their orientation, feminist women's organizations view gender as a fundamental ordering principle of their programmes and activities. They try to promote the transformation of gender and related hierarchies within society through their programmes and activities.

Feminist organizations in Turkey work on subjects such as domestic violence, women's empowerment and consciousness raising. There are several feminist journals that are published in association with these feminist organizations, and they also address issues of domestic violence, legal reform, sexual harassment, discrimination in the work place and the raising of feminist consciousness.

Feminist women's groups mostly deal with women's strategic gender needs. These organizations challenge the basic premises of the existing gendered division of labour where gender division of labour is perceived as natural, and gender is seen as the organizing principle of the social division of labour. Principally, they address strategic gender needs. For instance, the Altindag Women's Solidarity Foundation and the Purple Roof Women's Shelter provide battered women with a welcome refuge from domestic violence. With additional therapy and employment services, they help put women back on their feet. Secondly, their programmes make women and women's needs a priority. For instance, the community-based, participatory child care centres of the Foundation for the Support of Women's Work help free women's time and give them peace of mind with quality child care while they are working. A few recent programmes run by feminist women's organizations also cater for women's practical gender needs.

The programmes of feminist women's organizations have several limitations. Firstly, although very strong in their social goals and objectives, they reach only a limited number of women in urban working-class or squatter areas. This is partially due to their restricted funds. Funds and activities are limited since they do not belong to a larger political movement in the country like the Kemalists and the Islamists. People in traditional communities are also suspicious of feminist women's organizations. Several women in these communities indicated that male members of their family 
would not let them participate in the organizations' programmes because they 'put wrong thoughts into the minds of women' and encouraged them to be disrespectful to men (see Table 1).

A review of the women's organizations in 1990s Turkey points to political orientations which are extensions of larger political agendas. Despite their differences in how they position women in society, the women's organizations reviewed for this research share certain characteristics. Firstly, most women's organizations have limited international and national sponsorship in Turkey. Those organizations which benefit from extensive international donor support have family planning agendas. Women's organizations that have extensive national funding through private funds are those with religious agendas. Those with family planning agendas receive support from international donor agencies such as the International Planned Parenthood Foundation (IPPF). Those with religious agendas receive backing from other private religious funds and organizations such as the Islamic Municipalities and foundations.

Secondly, programmes of women's organizations in Turkey reach only a small number of people. The extent of the programmes is very limited, both in the number of projects launched and the number of women reached. The lack of financial resources is the main reason for these limitations. It is costly to launch multi-location projects without an organizational infrastructure and network. Building such an infrastructure needs a constant flow of funds as well as high levels of institutionalization.

Thirdly, women who work in these organizations do so largely on a voluntary basis. Most of these organizations are driven by the initiatives and hard work of only a few individuals. This may be an advantage in starting up institutions but in the long run creates problems in achieving institutionalization and continuity.

This article has attempted to view women's organizations in Turkey in their political contexts by identifying the types of gender need they address, practical or strategic. It also positions women's organizations in their historical and political national contexts by reviewing their programmes and political agendas as Kemalist, Islamist and feminist women's organizations.

Women's organizations in Turkey are mostly underfinanced and limited in both scope and degree of institutionalization. However, together they represent a diverse and rich form of women's agency. They are all centrally positioned in the social and political cultures that are historically and currently struggling to establish their model of development and modernity in Turkey. The programmes and political agendas of women's organizations reflect larger national projects. In the case of Kemalist and Islamic women's groups, the project of modernity is heavily dependent on the symbolic role and image of women for social change. 
Feminist women's organizations, in contrast to the Kemalist and Islamic women's groups, target change for women for themselves rather than as symbols of other political agendas. It is only the feminist women's organizations which perceive women as independent agents of society and tailor their activities accordingly. They neither nurture a dependency, as in the case of Islamic women's organizations, nor reinforce traditional gender roles of women, as seen in the sewing and embroidery courses for women developed by Kemalist women's organizations.

There are similarities between Kemalist and feminist women's organizations in terms of their commitment to secularism. Their strategies for dealing with Islamist groups differ considerably. While Kemalist women's groups have an exclusionary attitude with respect to Islamic women's organizations, feminist women's groups look for common platforms on which to discuss issues and reach a better understanding with Islamic women's groups.

In conclusion, in contemporary Turkey, the growing polarization of the political climate provides an atmosphere in which women's organizations can prosper. Our findings suggest that women's organizations, Kemalist, Feminist and Islamic, are flourishing either as a reaction to or in support of the initial project of modernity that the modern Turkish Republic initiated in the 1920s. Women's organizations, as civil society agents and as agents of development and change for women, are becoming more significant elements of the society in the 1990s despite the institutional and political constraints that they face.

While Kemalist women's groups receive support from secular communities and Islamic women's groups are funded by religious communities, it is the feminist women's groups which have the least financial and political support from any group or institution in the country. The fact that feminist groups are not connected to any mainstream political movement makes their position vulnerable in terms of financial sustainability, more so than any of the other women's organizations. Moreover, the conservative gender ideology that is prevalent in Turkey does not give due credit to the work of feminist organizations.

The polarization in the political arena between the Kemalist modernity project and the Islamist project of development will increase the number of women's organizations which define themselves in their association with Islamist or Kemalist ideology. As the Islamists advocate the view that a woman's place is strictly in the home as a mother and a wife, Kemalists advocate women's full political and economic participation in public life in addition to their family responsibilities. The Islamist rhetoric carries the contractions of women as housewives and mothers on the one hand and as activists for furthering the Islamist cause on the other. The Kemalist 
women's groups do not address the issue of the double workday - the dual labour women have to perform in the home and in the workplace. It is only the feminist NGOs that tackle the problem of the time constraints on women and advocate increased responsibility of the state, private institutions and men in sharing the housework and child care burdens of women. While their voice is still only heard by a few, the issues they raise are slowly finding a place in the social consciousness of Turkey.

\section{NOTES}

This article received the best essay award in the competition on "Girls and Young Women and the Women's Movement', sponsored by RC32 (Women in Society Rescarch Committee) of the International Sociological Association, 1998. This study is based on field work for a Women's Microenterprises Project that was conducted for the Directorate General for the Status and Problems of Women in Turkey.

1. Metin Heper and Ahmet Evin. Politics in the Third Turkish Republic (Boulder, CO: Westview Press, 1994).

2. Sirin Tekeli (ed.), Women in Modern Turkish Society (London: Zed Books, 1995).

3. J.P. Therien, 'Non-governmental Organizations and the International Development Assistance', Revue Canadienne des Etudes de Développement (Canadian Journal of Development Studies), Vol.12, No.2 (1991), pp.263-80.

4. Caroline Moser, Gender Planning and Development: Theory, Practice and Training (London: Routledge, 1993).

5. Ibid.

6. V. Spike Peterson and Anne Sison Runyan. Global Gender Issues (Boulder, CO: Westview Press, 1993) and Caroline Moser, Gender Planning and Development.

7. Deniz Kandiyoti, Women, Islam and the State (Philadelphia: Temple University Press, 1991).

8. Tekeli, Women in Modern Turkish Society.

9. Turkiye Ekonomik ve Toplumsal Tarih Vakfi, Sivil Toplum Kuruluslari Rehberi (NGO Directory of Turkey) (Istanbul, 1996).

10. John Magill, Simel Esim et al., 'Supporting Women Owned Business in Turkey: A Discussion of Needs, Problems, Opportunities and Strategies, A Report prepared for the Republic of Turkey, Prime Ministry, Directorate General on the Status and Problems of Women' (Ankara, 1995). 